\title{
Morinagadepsin, a Depsipeptide from the Fungus Morinagamyces vermicularis gen. et comb. nov.
}

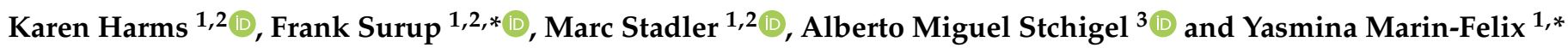 \\ 1 Department Microbial Drugs, Helmholtz Centre for Infection Research, Inhoffenstrasse 7, \\ 38124 Braunschweig, Germany; Karen.Harms@helmholtz-hzi.de (K.H.); \\ Marc.Stadler@helmholtz-hzi.de (M.S.) \\ 2 Institute of Microbiology, Technische Universität Braunschweig, Spielmannstrasse 7, \\ 38106 Braunschweig, Germany \\ 3 Mycology Unit, Medical School and IISPV, Universitat Rovira i Virgili, C/ Sant Llorenç 21, 43201 Reus, \\ Tarragona, Spain; albertomiguel.stchigel@urv.cat \\ * Correspondence: Frank.Surup@helmholtz-hzi.de (F.S.); Yasmina.MarinFelix@helmholtz-hzi.de (Y.M.-F.)
}

check for updates

Citation: Harms, K.; Surup, F.; Stadler, M.; Stchigel, A.M.;

Marin-Felix, Y. Morinagadepsin, a Depsipeptide from the Fungus Morinagamyces vermicularis gen. et comb. nov. Microorganisms 2021, 9 , 1191. https://doi.org/10.3390/ microorganisms 9061191

Academic Editor: Giovanni Di Bonaventura

Received: 23 April 2021

Accepted: 27 May 2021

Published: 31 May 2021

Publisher's Note: MDPI stays neutral with regard to jurisdictional claims in published maps and institutional affiliations.

Copyright: (c) 2021 by the authors. Licensee MDPI, Basel, Switzerland. This article is an open access article distributed under the terms and conditions of the Creative Commons Attribution (CC BY) license (https:/ / creativecommons.org/licenses/by/ $4.0 /)$.

\begin{abstract}
The new genus Morinagamyces is introduced herein to accommodate the fungus Apiosordaria vermicularis as inferred from a phylogenetic study based on sequences of the internal transcribed spacer region (ITS), the nuclear rDNA large subunit (LSU), and partial fragments of ribosomal polymerase II subunit 2 ( $r p b 2$ ) and $\beta$-tubulin (tub2) genes. Morinagamyces vermicularis was analyzed for the production of secondary metabolites, resulting in the isolation of a new depsipeptide named morinagadepsin (1), and the already known chaetone B (3). While the planar structure of $\mathbf{1}$ was elucidated by extensive 1D- and 2D-NMR analysis and high-resolution mass spectrometry, the absolute configuration of the building blocks Ala, Val, and Leu was determined as -L by Marfey's method. The configuration of the 3-hydroxy-2-methyldecanyl unit was assigned as $22 R, 23 R$ by $J$-based configuration analysis and Mosher's method after partial hydrolysis of the morinagadepsin to the linear derivative compound $\mathbf{2}$. Compound $\mathbf{1}$ showed cytotoxic activity against the mammalian cell lines KB3.1 and L929, but no antimicrobial activity against the fungi and bacteria tested was observed, while 2 was inactive. Compound 3 was weakly cytotoxic against the cell line L929, but did not show any antimicrobial activity.
\end{abstract}

Keywords: cytotoxicity; depsipeptide; Morinagamyces; morinagadepsin; Schizotheciaceae; secondary metabolites; Sordariales

\section{Introduction}

The genus Apiosordaria was introduced by von Arx and Gams in 1967 to accommodate Pleurage verruculosa, which differs from the other species of the genus by its ornamented ascospores [1]. Apiosordaria included species with two-celled ascospores with an ellipsoidal to subglobose ornamented upper cell, and with a triangular to cylindrical mostly smooth-walled lower cell [1-3]. The genera Apiosordaria and Triangularia were traditionally segregated by the shape of the upper cell of their ascospores, which are more or less conical in Triangularia fide Guarro and Cano [2]. However, in a recent phylogenetic study, the type strains of both genera were placed in the same monophyletic clade of the family Podosporaceae, resulting in the synonymization of Apiosordaria with Triangularia [4]. However, most species of Apiosordaria remained with an uncertain taxonomic placement. Subsequently, $A$. sacchari and A. striatispora were transferred to Triangularia, and A. globosa, A. hispanica, and A. vestita to Jugulospora, based on phylogenetic and morphological data [5]. In the present phylogenetic study, based on analysis of sequences of the internal transcribed spacer region (ITS), the nuclear rDNA large subunit (LSU), and fragments of ribosomal polymerase II subunit 2 ( $r p b 2)$ and $\beta$-tubulin ( $t u b 2)$ genes, the new genus Morinagamyces is introduced to accommodate $A$. vermicularis, with phylogenetic affiliation to the recently established family Schizotheciaceae [5]. 
The order Sordariales includes producers of a great diversity of biologically active secondary metabolites [6-9], with potential uses as drugs. In this context, the ex-type strain of Morinagamyces vermicularis was tested for the production of bioactive compounds, leading to the isolation of a new depsipeptide named morinagadepsin (1), whose structure elucidation, antimicrobial activity, and cytotoxicity are presented herein. Chaetone B (3) was also produced, and its antimicrobial and cytotoxic activity tested.

\section{Materials and Methods}

\subsection{Molecular Study}

DNA of the ex-type strain of Apiosordaria vermicularis was extracted and purified directly from colonies according to the Fast DNA Kit protocol (MP Biomedicals, Solon, Ohio). The amplification of the ITS, D1-D3 domains of the LSU, rpb2, and tub2 was performed according to White et al. [10] (ITS), Vilgalys and Hester [11] (LSU), and Miller and Huhndorf [12] (rpb2 and tub2). PCR products were purified and sequenced at Macrogen Europe (Amsterdam, The Netherlands) with a 3730XL DNA analyzer (Applied Biosystems). Consensus sequences were obtained using SeqMan (version 7.0.0; DNASTAR, Madison, WI, USA). The phylogenetic analysis was carried out based on the combination of the four loci (ITS, LSU, rpb2, and tub2) sequences of the ex-type strain of A. vermicularis and selected members of the Sordariales, with Camarops amorpha SMH 1450 as outgroup. Each locus was aligned separately using MAFFT v. 7 [13] and manually adjusted in MEGA v. 10.2.4 [14]. Individual gene phylogenies were checked for conflicts before the four loci datasets were concatenated [15,16]. The Maximum Likelihood (ML) and Bayesian Inference (BI) analysis including the four loci were performed as described by Harms et al. [9]. The best evolutionary model for each sequence dataset was calculated using MrModeltest v. 2.3 [17]. Bootstrap support (bs) $\geq 70 \%$ and posterior probability values (pp) $\geq 0.95$ were considered significant [18]. The sequences generated in this study are deposited in GenBank (Table 1) and the alignment used in the phylogenetic analysis is deposited in TreeBASE (S28234).

Table 1. Strains of the order Sordariales included in the phylogenetic study. GenBank accession numbers in bold correspond to the newly generated sequences. Taxonomic novelty is indicated in italic bold.

\begin{tabular}{|c|c|c|c|c|c|c|}
\hline \multirow{2}{*}{ Taxa } & \multirow{2}{*}{ Strain } & \multicolumn{4}{|c|}{ GenBank Accession Number } & \multirow{2}{*}{ Source } \\
\hline & & LSU & ITS & $r p b 2$ & $t u b 2$ & \\
\hline Anopodium ampullaceum* & MJR 40/07 & KF557662 & - & - & KF557701 & [19] \\
\hline Apiosordaria microcarpa* & CBS $692.82^{\mathrm{T}}$ & MK926841 & MK926841 & MK876803 & - & {$[4]$} \\
\hline Areotheca ambigua & CBS 215.60 & AY999114 & AY999137 & - & - & [20] \\
\hline Areotheca areolata & UAMH 7495 & AY587936 & AY587911 & AY600275 & AY600252 & [21] \\
\hline Arnium cirriferum ${ }^{*}$ & CBS 120041 & KF557673 & - & - & KF557709 & [19] \\
\hline \multirow[t]{2}{*}{ Arnium hirtum* } & E00204950 & KF557675 & - & - & KF557711 & [19] \\
\hline & E00204487 & KF557676 & - & - & KF557712 & [19] \\
\hline Bellojisia rhynchostoma* & CBS 118484 & EU999217 & - & - & - & [22] \\
\hline Camarops amorpha & SMH 1450 & AY780054 & - & AY780156 & AY780093 & [12] \\
\hline Cercophora mirabilis & CBS 120402 & KP981429 & MT784128 & KP981611 & KP981556 & [5] \\
\hline Cercophora sparsa* & JF 00229 & AY587937 & AY587912 & - & AY600253 & {$[21]$} \\
\hline Cercophora sulphurella* & SMH 2531 & AY587938 & AY587913 & AY600276 & AY600254 & [21] \\
\hline Chaetomium globosum & CBS $160.62^{\mathrm{T}}$ & MH869713 & KT214565 & KT214666 & - & {$[23,24]$} \\
\hline Cladorrhinum foecundissimum & CBS $180.66^{\mathrm{T}}$ & MK926856 & MK926856 & MK876818 & - & [4] \\
\hline Cladorrhinum hyalocarpum & CBS $322.70^{\mathrm{T}}$ & MK926857 & MK926857 & MK876819 & - & {$[4]$} \\
\hline Cladorrhinum intermedium & CBS $433.96^{\mathrm{T}}$ & MK926859 & MK926859 & MK876821 & - & [4] \\
\hline Corylomyces selenosporus* & CBS $113930^{\mathrm{T}}$ & DQ327607 & MT784130 & KP981612 & KP981557 & {$[5,25]$} \\
\hline Corynascus sepedonium & CBS $111.69^{\mathrm{T}}$ & MH871003 & MH859271 & FJ666394 & - & {$[23,26]$} \\
\hline Corynascella humicola & CBS $337.72^{\mathrm{T}}$ & MH872209 & MH860493 & - & - & [23] \\
\hline Diplogelasinospora grovesii & CBS $340.73^{\mathrm{T}}$ & MH872401 & MH860693 & - & - & [23] \\
\hline Diplogelasinospora moalensis & CBS $136018^{\mathrm{T}}$ & KP981430 & HG514152 & KP981613 & KP981558 & {$[5,27]$} \\
\hline Diplogelasinospora princeps & FMR 13415 & KP981432 & - & KP981615 & KP981560 & [5] \\
\hline Echria gigantospora & F77-1 & KF557674 & - & - & KF557710 & [19] \\
\hline Echria macrotheca & Lundqvist 2311 & KF557684 & - & - & KF557715 & [19] \\
\hline
\end{tabular}


Table 1. Cont

\begin{tabular}{|c|c|c|c|c|c|c|}
\hline \multirow{2}{*}{ Taxa } & \multirow{2}{*}{ Strain } & \multicolumn{4}{|c|}{ GenBank Accession Number } & \multirow{2}{*}{ Source } \\
\hline & & LSU & ITS & $r p b 2$ & $t u b 2$ & \\
\hline Immersiella caudata & SMH 3298 & AY436407 & - & AY780161 & AY780101 & {$[12,28]$} \\
\hline Immersiella immersa & SMH 4104 & AY436409 & - & AY780181 & AY780123 & {$[12,28]$} \\
\hline Jugulospora antarctica & IMI $381338^{\mathrm{T}}$ & KP981433 & - & KP981616 & KP981561 & [5] \\
\hline Jugulospora carbonaria & ATCC 34567 & AY346302 & - & AY780196 & AY780141 & {$[12,29]$} \\
\hline \multirow[t]{4}{*}{ Jugulospora rotula } & CBS 110112 & KP981434 & - & KP981617 & KP981562 & [5] \\
\hline & CBS 110113 & KP981435 & - & KP981618 & KP981563 & [5] \\
\hline & FMR 12690 & KP981437 & MT784133 & KP981620 & KP981565 & [5] \\
\hline & FMR 12781 & KP981438 & MT784134 & KP981621 & KP981566 & [5] \\
\hline Jugulospora vestita & CBS $135.91^{\mathrm{T}}$ & MT785872 & MT784135 & MT783824 & MT783825 & [5] \\
\hline Lasiosphaeria glabrata & TL 4529 & AY436410 & AY587914 & AY600277 & AY600255 & {$[21,28]$} \\
\hline Lasiosphaeria ovina & SMH 1538 & AF064643 & AY587926 & AY600287 & AF466046 & {$[21,30,31]$} \\
\hline Lasiosphaeria rugulosa & SMH 1518 & AY436414 & AY587933 & AY600294 & AY600272 & {$[21,28]$} \\
\hline Lundquistomyces karachiensis & CBS 657.74 & KP981447 & MK926850 & KP981630 & KP981478 & {$[4,5]$} \\
\hline Lundqvistomyces tanzaniensis & TRTC $51981^{\mathrm{T}}$ & AY780081 & MH862260 & AY780197 & AY780143 & {$[12,23]$} \\
\hline Morinagamyces vermicularis & CBS $303.81^{\mathrm{T}}$ & KP981427 & МТ904879 & KP981609 & KP981554 & Present study \\
\hline Naviculispora terrestris & CBS $137295^{\mathrm{T}}$ & KP981439 & MT784136 & KP981622 & KP981567 & [5] \\
\hline Neurospora pannoica & TRTC 51327 & AY780070 & - & AY780185 & AY780126 & [12] \\
\hline Podospora didyma* & CBS 232.78 & AY999100 & AY999127 & - & - & [20] \\
\hline Podospora fimicola & CBS $482.64^{\mathrm{ET}}$ & KP981440 & MK926862 & KP981623 & KP981568 & {$[4,5]$} \\
\hline Podospora sacchari & CBS $713.70^{\mathrm{T}}$ & KP981425 & MH859915 & KP981607 & KP981552 & {$[5,23]$} \\
\hline Podospora striatispora & CBS $154.77^{\mathrm{T}}$ & KP981426 & MT784137 & KP981608 & KP981553 & [5] \\
\hline Pseudoechria curvicolla & CBS 259.69 & MH871036 & MH859302 & - & - & [23] \\
\hline Pseudoechria decidua & CBS $254.71^{\mathrm{T}}$ & MK926842 & MK926842 & MK876804 & - & {$[4]$} \\
\hline Pseudoechria. prolifica & CBS $250.71^{\mathrm{T}}$ & MK926848 & MK926848 & MK876810 & - & [5] \\
\hline Pseudoneurospora canariensis & FMR $12156^{\mathrm{T}}$ & MH877580 & - & - & HG423208 & {$[23,27]$} \\
\hline Pseudorhypophila mangenotii & CBS $419.67^{\mathrm{T}}$ & KP981444 & MT784143 & KР981627 & KP981571 & [5] \\
\hline \multirow[t]{2}{*}{ Pseudorhypophila marina } & CBS $155.77^{\mathrm{T}}$ & MK926851 & MK926851 & MK876813 & - & [4] \\
\hline & CBS $698.96^{\mathrm{T}}$ & MK926853 & MK926853 & MK876815 & - & [4] \\
\hline Pseudorhypophila pilifera & CBS $413.73^{\mathrm{T}}$ & MK926852 & MK926852 & MK876814 & - & [4] \\
\hline Pseudoschizothecium atropurpureum & SMH 3073 & AY780057 & - & AY780160 & AY780100 & [12] \\
\hline Rinaldiella pentagonospora & CBS $132344^{\mathrm{T}}$ & KP981442 & MH866007 & KP981625 & KP981570 & {$[5,23]$} \\
\hline Rhypophila cochleariformis & CBS 249.71 & AY999098 & AY999123 & - & - & [20] \\
\hline Rhypophila decipiens & CBS 258.69 & AY780073 & KX171946 & AY780187 & AY780130 & $\begin{array}{c}\text { [12], Miller } \\
\text { [unpubl. data] }\end{array}$ \\
\hline Rhypophila pleiospora & TNM F16889 & - & EF197084 & - & - & [32] \\
\hline Schizothecium fimbriatum & CBS 144.54 & AY780075 & AY999115 & AY780189 & AY780132 & {$[12,20]$} \\
\hline Schizothecium inaequale & CBS $356.49^{\mathrm{T}}$ & MK926846 & MK926846 & MK876808 & - & [4] \\
\hline Schizothecium selenosporum & CBS $109403^{\mathrm{T}}$ & MK926849 & MK926849 & MK876811 & - & {$[4]$} \\
\hline Sordaria fimicola & SMH 4106 & AY780079 & - & AY780194 & AY780138 & [12] \\
\hline Triangularia allahabadensis & CBS $724.68^{\mathrm{T}}$ & MK926865 & MK926865 & MK876827 & - & {$[4]$} \\
\hline Triangularia backusii & CBS 539.89 ${ }^{\text {IsoT }}$ & MK926866 & MK926866 & MK876828 & - & [4] \\
\hline Triangularia backusii & FMR 12439 & KP981423 & MT784138 & KP981605 & KP981550 & [5] \\
\hline Triangularia backusii & FMR 13591 & KP981424 & MT784139 & KР981606 & KP981551 & [5] \\
\hline Triangularia bambusae & CBS $352.33^{\mathrm{T}}$ & MK926868 & MK926868 & MK876830 & - & [4] \\
\hline Triangularia batistae & CBS $381.68^{\mathrm{T}}$ & KP981443 & MT784140 & KP981626 & KP981577 & [5] \\
\hline Triangularia longicaudata & CBS $252.57^{\mathrm{T}}$ & MK926871 & MK926871 & MK876833 & - & [4] \\
\hline Triangularia setosa & FMR 12787 & KP981441 & MT784144 & KP981624 & KP981569 & {$[5]$} \\
\hline Triangularia tetraspora & FMR 5770 & AY999130 & AY999108 & - & - & $\begin{array}{c}\text { Cai et al. } \\
\text { [unpubl. data] }\end{array}$ \\
\hline Triangularia verruculosa & CBS 148.77 & MK926874 & MK926874 & MK876836 & - & [4] \\
\hline Zopfiella tabulata & CBS 230.78 & MK926854 & MK926854 & MK876816 & - & [4] \\
\hline Zopfiella tardifaciens* & CBS $670.82^{\mathrm{T}}$ & MK926855 & MK926855 & MK876817 & - & [4] \\
\hline Zygopleurage zygospora & SMH 4219 & AY346306 & - & - & AY780147 & {$[12,29]$} \\
\hline
\end{tabular}

ATCC: American Type Culture Collection, Virginia, USA; CBS: Westerdijk Fungal Biodiversity Institute, Utrecht, the Netherlands; FMR: Facultat de Medicina, Reus, Spain; IMI: International Mycological Institute, CABI-Bioscience, Egham, UK; TNM: Herbarium of National Museum of Natural Science, Taiwan; TRTC: Royal Ontario Museum, Toronto, Canada; UAMH: UAMH Center for Global Microfungal Biodiversity, University of Toronto, Canada; JF, Lundqvist, MJR, SMH, and TL: personal collections of Jacques Fournier, Nils Lundqvist, Michael J. Richardson, Sabine M. Huhndorf, and Thomas Læssøe, respectively; and n/a: not available. ET, IsoT and T indicates ex-epitype, ex-isotype and ex-type strains, respectively. * Taxa with generic names applied in the broad sense (sensu lato), not necessarily reflecting molecular phylogenetic relationships. 


\subsection{Fermentation and Extraction}

The fungus was grown in yeast malt extract agar (YM agar; malt extract $10 \mathrm{~g} / \mathrm{L}$, yeast extract $4 \mathrm{~g} / \mathrm{L}$, D-glucose $4 \mathrm{~g} / \mathrm{L}$, agar $20 \mathrm{~g} / \mathrm{L}, \mathrm{pH} 6.3$ before autoclaving [33]) at $23^{\circ} \mathrm{C}$. Later, the colonies were cut into small pieces using a cork borer $(1 \mathrm{~cm} \times 1 \mathrm{~cm})$ and 8 pieces were placed into a $200 \mathrm{~mL}$ Erlenmeyer flask containing $100 \mathrm{~mL}$ of yeast malt extract broth (YM broth; malt extract $10 \mathrm{~g} / \mathrm{L}$, yeast extract $4 \mathrm{~g} / \mathrm{L}$, D-glucose $4 \mathrm{~g} / \mathrm{L}, \mathrm{pH} 6.3$ before autoclaving) at $23{ }^{\circ} \mathrm{C}$ and under shake condition at $140 \mathrm{rpm}$. After 7 days, $6 \mathrm{~mL}$ of this seed culture were transferred to 40 conical flasks of $500 \mathrm{~mL}$ containing solid rice medium (BRFT, brown rice $28 \mathrm{~g}$ as well as $0.1 \mathrm{~L}$ of base liquid (yeast extract $1 \mathrm{~g} / \mathrm{L}$, di-sodium tartrate di-hydrate $0.5 \mathrm{~g} / \mathrm{L}, \mathrm{KH}_{2} \mathrm{PO}_{4} 0.5 \mathrm{~g} / \mathrm{L}$ [34])) per flask. The rice cultures were incubated for 15 days at $23{ }^{\circ} \mathrm{C}$.

For compound extraction, the mycelia in BRFT were covered with acetone, and sonicated in an ultrasonic bath for $30 \mathrm{~min}$ at $40{ }^{\circ} \mathrm{C}$. The acetone extract was separated from the mycelium by filtration throughout a cellulose filter paper (MN 615 1/4 Ø $185 \mathrm{~mm}$, Macherey-Nagel GmbH \& Co. KG, Düren, Germany), and the mycelium was sonicated and extracted again. Both extracts were combined, and the acetone was evaporated to an aqueous residue in vacuo at $40{ }^{\circ} \mathrm{C}$. The resulting aqueous phase was extracted twice with an equal amount of ethyl acetate in a separatory funnel. The ethyl acetate fraction was evaporated to dryness in vacuo (evaporator: Heidolph Instruments GmbH \& Co. KG, Germany; pump: Vacuubrand GmbH \& Co. KG, Wertheim am Main, Germany) at $40{ }^{\circ} \mathrm{C}$. Afterwards, the ethyl acetate extract was dissolved in methanol. This was followed by extraction with an equal amount of heptane in a separatory funnel. This later step was repeated with the methanol phase obtained, which was evaporated to dryness in vacuo at $40{ }^{\circ} \mathrm{C}$. The extracts were combined, dried in vacuo at $40{ }^{\circ} \mathrm{C}$ and weighed. Methanol extract yield was $1345 \mathrm{mg}$.

\subsection{Compound Isolation}

For compound isolation, the methanol extract dissolved in $\mathrm{MeOH}$ was portioned to $5 \times 269 \mathrm{mg}$ and separated using a PLC 2250 preparative HPLC system (Gilson, Middleton, WI, USA) with a Nucleodur ${ }^{\circledR}$ C18ec column $(125 \times 40 \mathrm{~mm}, 7 \mu \mathrm{m}$; Macherey-Nagel, Düren, Germany) as stationary phase and the following conditions: solvent $\mathrm{A}: \mathrm{H}_{2} \mathrm{O}+0.1 \%$ formic acid, solvent $\mathrm{B}$ : Acetonitrile $(\mathrm{ACN})+0.1 \%$ formic acid; flow: $45 \mathrm{~mL} / \mathrm{min}$, fractionation: $15 \mathrm{~mL}$, gradient: isocratic conditions at $20 \% \mathrm{~B}$ for $2 \mathrm{~min}$, followed by an increase to $32 \% \mathrm{~B}$ in $8 \mathrm{~min}$, then increase to $65 \% \mathrm{~B}$ in $25 \mathrm{~min}$, followed by an increase to $100 \% \mathrm{~B}$ in $10 \mathrm{~min}$, followed by isocratic conditions of $100 \%$ B for $10 \mathrm{~min}$. This yielded compound 1 (48.4 $\mathrm{mg}$, $\left.t_{R}=43.5-44 \mathrm{~min}\right)$ and compound $3\left(6.2 \mathrm{mg}, t_{R}=37-37.5 \mathrm{~min}\right)$.

\subsection{Chromatography and Spectral Methods}

Crude extract and pure compounds were dissolved to a concentration of 4.5 and $1 \mathrm{mg} / \mathrm{mL}$, respectively, in an acetone and methanol solution (1:1). Then they were analyzed in an UltiMate ${ }^{\circledR} 3000$ Series UHPLC system (Thermo Fisher Scientific, Waltman, MA, USA) connected to an ion trap mass spectrometer (ESI-Ion Trap-MS, amazon speed, Bruker, Billerica, MA, USA), utilizing a C18 Acquity ${ }^{\circledR}$ UPLC BEH column $(2.1 \times 50 \mathrm{~mm}, 1.7 \mathrm{~m}$; Waters, Milford, MA, USA) to obtain the electrospray ionization mass spectra (ESI-MS). Solvent $\mathrm{A}$ was $\mathrm{H}_{2} \mathrm{O}+0.1 \%$ formic acid and solvent $\mathrm{B}$ was $\mathrm{ACN}+0.1 \%$ formic acid. The gradient started with $5 \%$ of solvent B for $0.5 \mathrm{~min}$, followed by an increase to $100 \% \mathrm{~B}$ in $19.5 \mathrm{~min}$, and maintained in $100 \% \mathrm{~B}$ for $5 \mathrm{~min}$ more, with a flow rate of $0.6 \mathrm{~mL} / \mathrm{min}$. The $\mathrm{UV} /$ vis spectra were recorded by diode array detection (DAD) in a range from 190-600 nm.

High-resolution electrospray ionization mass spectra (HR-ESI-MS) were recorded with an Agilent 1200 Infinity Series HPLC-UV system (Agilent Technologies, Santa Clara, CA, USA) connected to a time-of-flight mass spectrometer (ESI-TOF-MS, Maxis, Bruker, Billerica, MA, USA) (scan range 100-2500 m/ $z$, rate $2 \mathrm{~Hz}$, capillary voltage $4500 \mathrm{~V}$, dry temperature $200^{\circ} \mathrm{C}$ ), using the same HPLC conditions described in ESI-MS measurements. 
The 1D- and 2D- nuclear magnetic resonance (NMR) spectra of compounds 1 and 2 were recorded with an Avance III 700 spectrometer with a 5 mm TXI cryoprobe (Bruker, ${ }^{1} \mathrm{H}$ NMR: $700 \mathrm{MHz},{ }^{13} \mathrm{C}: 175 \mathrm{MHz}$, Billerica, MA, USA) and an Avance III 500 (Bruker, ${ }^{1} \mathrm{H}$ NMR: $500 \mathrm{MHz},{ }^{13} \mathrm{C}$ : $125 \mathrm{MHz}$, Billerica, MA, USA) spectrometer, respectively. The chemical shifts $\delta$ were referenced to the solvents DMSO- $d_{6}\left({ }^{1} \mathrm{H}, \delta=2.50 ;{ }^{13} \mathrm{C}, \delta=39.51\right)$, and pyridine- $d_{5}\left({ }^{1} \mathrm{H}, \delta=7.22 ;{ }^{13} \mathrm{C}, \delta=123.87\right)$.

Optical rotations were measured with an MCP 150 circular polarimeter at $20^{\circ} \mathrm{C}$ (Anton Paar, Graz, Austria) and UV/Vis spectra with a UV-2450 spectrophotometer (Shimadzu, Kyoto, Japan). The optical rotation was obtained in $\mathrm{MeOH}$ and the UV/Vis spectra were measured in ACN.

\subsection{Spectral Data}

2.5.1. Morinagadepsin (1)

White powder; $[\alpha]^{20} \mathrm{D}-93^{\circ}$ (c 0.001, MeOH); UV (ACN) $\lambda_{\max }(\log \varepsilon) 194$ (4.2); ${ }^{1} \mathrm{H}-$ NMR and ${ }^{13} \mathrm{C}-\mathrm{NMR}$ see Table 2; ESI-MS: $m / z 579(\mathrm{M}-\mathrm{H})^{-}$and $581(\mathrm{M}+\mathrm{H})^{+}$; HR-ESI-MS: $m / z 581.4275(\mathrm{M}+\mathrm{H})^{+}$(calculated for $\left.\mathrm{C}_{31} \mathrm{H}_{57} \mathrm{~N}_{4} \mathrm{O}_{6}, 581.4278\right)$.

Table 2. NMR data $\left({ }^{1} \mathrm{H} 700 \mathrm{MHz},{ }^{13} \mathrm{C} 175 \mathrm{MHz}\right)$ of morinagadepsin 1 in DMSO- $d_{6}$.

\begin{tabular}{|c|c|c|c|c|c|c|c|}
\hline Atom\# & Atom\# & C Shift & H Shift & Atom\# & Atom\# & C Shift & H Shift \\
\hline \multirow[t]{8}{*}{ Leu1 } & 1 & $170.9, \mathrm{C}$ & & Val & 16 & $172.4, \mathrm{C}$ & \\
\hline & 2 & $51.1, \mathrm{CH}$ & 4.39, ddd $(9.5,9.0,5.8)$ & & 17 & $58.0, \mathrm{CH}$ & $4.01, \mathrm{t}(7.4)$ \\
\hline & $2 \mathrm{NH}$ & & 7.80, br d $(7.5)$ & & $17 \mathrm{NH}$ & & $6.91, \mathrm{~d}(7.4)$ \\
\hline & 3 & 39.6, $\mathrm{CH}_{2}$ & $1.74, \mathrm{~m}$ & & 18 & $30.5, \mathrm{CH}$ & $1.83, \mathrm{~m}$ \\
\hline & 3 & & $1.67, \mathrm{~m}$ & & 19 & $18.74, \mathrm{CH}_{3}$ & $0.87, \mathrm{~m}^{*}$ \\
\hline & 4 & $24.1, \mathrm{CH}$ & $1.67, \mathrm{~m}$ & & 20 & $18.77, \mathrm{CH}_{3}$ & $0.87, \mathrm{~m}^{*}$ \\
\hline & 5 & $22.5, \mathrm{CH}_{3}$ & $0.91, \mathrm{~d}(6.5)$ & HMD & 21 & $172.5, \mathrm{C}$ & \\
\hline & 6 & 21.7, $\mathrm{CH}_{3}$ & $0.86, \mathrm{~m}^{*}$ & & 22 & $45.8, \mathrm{CH}$ & $2.47, \mathrm{gd}(7.3,4.8)$ \\
\hline \multirow[t]{4}{*}{ Ala1 } & 7 & $171.5, \mathrm{C}$ & & & 23 & $75.1, \mathrm{CH}$ & 4.92, ddd $(8.7,4.8,4.0)$ \\
\hline & 8 & $49.8, \mathrm{CH}$ & $3.96, \mathrm{gd}(7.5,6.0)$ & & 24 & $32.1, \mathrm{CH}_{2}$ & $1.44, \mathrm{~m}^{*}$ \\
\hline & $8 \mathrm{NH}$ & & $7.98, \mathrm{~d}(6.0)$ & & 24 & & $1.35, \mathrm{~m}^{*}$ \\
\hline & 9 & $16.1, \mathrm{CH}_{3}$ & $1.37, \mathrm{~d}$ & & 25 & $24.5, \mathrm{CH}_{2}$ & $1.05, \mathrm{~m}^{*}$ \\
\hline \multirow[t]{8}{*}{ Leu2 } & 10 & $170.7, \mathrm{C}$ & & & 26 & $28.59, \mathrm{CH}_{2}$ & $1.19, \mathrm{~m}^{*}$ \\
\hline & 11 & $53.7, \mathrm{CH}$ & $3.53, \mathrm{~m}$ & & 27 & $28.61, \mathrm{CH}_{2}$ & $1.19, \mathrm{~m}^{*}$ \\
\hline & $11 \mathrm{NH}$ & & $9.30, \mathrm{~d}(7.0)$ & & 28 & $31.1, \mathrm{CH}_{2}$ & $1.19, \mathrm{~m}^{*}$ \\
\hline & 12 & 36.6, $\mathrm{CH}_{2}$ & $1.54, \mathrm{~m}^{*}$ & & 29 & $22.1, \mathrm{CH}_{2}$ & $1.24, \mathrm{~m}^{*}$ \\
\hline & 12 & & $1.99, \mathrm{~m}$ & & 30 & $13.9, \mathrm{CH}_{3}$ & $0.84, \mathrm{t}(7.1)$ \\
\hline & 13 & $24.7, \mathrm{CH}$ & $1.57, \mathrm{~m}^{*}$ & & 31 & $14.8, \mathrm{CH}_{3}$ & $1.05, \mathrm{~d}(7.3)$ \\
\hline & 14 & 23.6, $\mathrm{CH}_{3}$ & $0.91, \mathrm{~d}(6.5)$ & & & & \\
\hline & 15 & $22.5, \mathrm{CH}_{3}$ & $0.87, \mathrm{~m}^{*}$ & & & & \\
\hline
\end{tabular}

* Signals overlapping in the ${ }^{1} \mathrm{H}-\mathrm{NMR}$ spectrum.

\subsubsection{Chaetone B (3)}

White to yellow oil; ${ }^{1} \mathrm{H}-\mathrm{NMR}$ and ${ }^{13} \mathrm{C}-\mathrm{NMR}$ were in good agreement with the literature [35]; ESI-MS: $m / z 301(\mathrm{M}+\mathrm{H})^{+}$; HR-ESI-MS: $m / z 301.1068(\mathrm{M}+\mathrm{H})^{+}$(calculated for $\left.\mathrm{C}_{17} \mathrm{H}_{17} \mathrm{O}_{5}, 301.1076\right)$.

\subsection{Determination of Amino Acid Stereochemistry}

Determination of amino acid stereochemistry of $\mathbf{1}$ was performed with Marfey's reagent (1-fluoro-2,4-dinitrophenyl-5-L-valinamide (FDAA) (Sigma-Aldrich, Deisenhofen, Germany)) following the protocol described by Viehrig et al. [36] with slight modifications. Compound 1 ( $1 \mathrm{mg}$ ) was hydrolyzed with $6 \mathrm{~N} \mathrm{HCl}$ at $90{ }^{\circ} \mathrm{C}$ for $18 \mathrm{~h}$. The hydrolysate was evaporated to dryness and redissolved in water $(200 \mu \mathrm{L})$. Then, $1 \mathrm{~N} \mathrm{NaHCO}_{3}(20 \mu \mathrm{L})$ and $1 \%$ FDAA $\left(100 \mu \mathrm{L}\right.$ in acetone) were added. The solution was heated at $40{ }^{\circ} \mathrm{C}$ for $40 \mathrm{~min}$. After cooling down, the solution was neutralized with $2 \mathrm{~N} \mathrm{HCl}$ using $\mathrm{pH}$ paper and the sample was dried. The amino acids found in $\mathbf{1}$ were used as standards (D-L-Val (Sigma- 
Aldrich, Deisenhofen, Germany), L-Val (Sigma-Aldrich, Deisenhofen, Germany), D-L-Leu (Sigma-Aldrich, Deisenhofen, Germany), L-Leu (Sigma-Aldrich, Deisenhofen, Germany), L-Ala (Merck KGaA, Darmstadt, Germany), and D-Ala (Sigma-Aldrich, Deisenhofen, Germany)) and treated as explained above for the hydrolysate of $\mathbf{1}$. All the resulting products were dissolved in $1 \mathrm{~mL} \mathrm{MeOH}$ and analyzed with the UHPLC system connected to an ion trap mass spectrometer described above. The retention times in minutes of the FDAA-derivatized amino acids were Ala 5.1; Leu 7.4; and Val 6.5. Retention time of the FDAA-derivatized standards were L-Ala 5.0; D-Ala $5.8 \mathrm{~m} / \mathrm{z} 340$ (M - H) ${ }^{-}$; L-Leu 7.4; D-Leu $8.4 \mathrm{~m} / z 382(\mathrm{M}-\mathrm{H})^{-}$; L-Val 6.5; and D-Val $7.5 \mathrm{~m} / z 368(\mathrm{M}-\mathrm{H})^{-}$. The retention times showed that compound $\mathbf{1}$ is built with L-amino acids.

\subsection{Partial Hydrolysis of Morinagadepsin to Compound $\mathbf{2}$}

For the hydrolysis of 1, the protocol described by Kwon et al. [37] was followed with slight modification. A portion of compound $1(14.5 \mathrm{mg})$ was dissolved in $1 \mathrm{~mL}$ of $5 \%$ $\mathrm{NaOMe}$ (dissolved in methanol) and stirred for $20 \mathrm{~h}$ at $40{ }^{\circ} \mathrm{C}$. Afterwards, the reaction was neutralized with $1 \mathrm{~N} \mathrm{HCl}$ using $\mathrm{pH}$ paper and evaporated to dryness. Preparative HPLC used an Agilent 1100 series system (Santa Clara, CA, USA) with a Gemini ${ }^{\circledR}$ C18ec column $(250 \times 21.2 \mathrm{~mm}, 7 \mu \mathrm{m}$; Phenomenex, Torrance, CA, USA) as stationary phase and the following conditions: solvent $\mathrm{A}: \mathrm{H}_{2} \mathrm{O}+0.1 \%$ formic acid, solvent $\mathrm{B}: \mathrm{ACN}+0.1 \%$ formic acid; flow: for $2 \mathrm{~min}$ at 17 to $20 \mathrm{~mL} / \mathrm{min}$ and afterwards at $20 \mathrm{~mL} / \mathrm{min}$; fractionation: $10 \mathrm{~mL} / \mathrm{min}$; and gradient: isocratic conditions at $5 \% \mathrm{~B}$ for $2 \mathrm{~min}$, followed by an increase to $55 \% \mathrm{~B}$ in $8 \mathrm{~min}$, then increase to $65 \% \mathrm{~B}$ in $30 \mathrm{~min}$, followed by an increase to $100 \% \mathrm{~B}$ in $10 \mathrm{~min}$, followed by isocratic conditions of $100 \% \mathrm{~B}$ for $10 \mathrm{~min}$. This yielded the pure compound $2\left(7.9 \mathrm{mg}, t_{R}=23.8-24.8 \mathrm{~min}\right)$.

\subsubsection{Spectral Data of the Linear Peptide (2)}

White powder; $[\alpha] 20 \mathrm{D}-30^{\circ}$ (c $\left.0.001, \mathrm{MeOH}\right) ; \mathrm{UV}(\mathrm{ACN}) \lambda \max (\log \varepsilon) 192(4.1) ;{ }^{1} \mathrm{H}-$ NMR $\delta_{\mathrm{H}} 9.54(\mathrm{br} \mathrm{d}, J=8.4 \mathrm{~Hz}, 11-\mathrm{NH}), 9.43(\mathrm{br} \mathrm{d}, J=7.3 \mathrm{~Hz}, 8-\mathrm{NH}), 9.23(\mathrm{br} \mathrm{d}, J=5.6 \mathrm{~Hz}$, 2-NH), 8.91 (br d, $J=9.0 \mathrm{~Hz}, 17-\mathrm{NH}), 5.28-5.20(\mathrm{~m}, 2-\mathrm{H}, 8-\mathrm{H}, 11-\mathrm{H}), 5.09(\mathrm{t}, J=8.3 \mathrm{~Hz}$, 17-H), $4.09(\mathrm{~m}, 23-\mathrm{H}), 2.91(\mathrm{qd}, J=7.1 \mathrm{~Hz}, 5.9 \mathrm{~Hz}, 22-\mathrm{H}), 2.44(\mathrm{dspt}, J=8.2 \mathrm{~Hz}, 6.9 \mathrm{~Hz}, 18-\mathrm{H})$, 2.06-1.82 (m, 3- $\left.\mathrm{H}_{2}, 4-\mathrm{H}, 12-\mathrm{H}_{2}, 13-\mathrm{H}\right), 1.79\left(\mathrm{~m}, 24-\mathrm{H}_{2}\right), 1.73\left(\mathrm{~m}, 25-\mathrm{H}_{\mathrm{a}}\right), 1.61(\mathrm{~d}, J=7.1 \mathrm{~Hz}$, 9- $\left.\mathrm{H}_{3}\right), 1.57\left(\mathrm{~m}, 25-\mathrm{H}_{\mathrm{b}}\right), 1.44\left(\mathrm{~d}, J=7.1 \mathrm{~Hz}, 31-\mathrm{H}_{3}\right), 1.29-1.18\left(\mathrm{~m} .26-\mathrm{H}_{2}-29-\mathrm{H}_{2}\right), 1.17(\mathrm{~d}$, $\left.J=6.9 \mathrm{~Hz}, 20-\mathrm{H}_{3}\right), 1.00\left(\mathrm{~d}, J=6.5 \mathrm{~Hz}, 5-\mathrm{H}_{3}\right), 0.91\left(\mathrm{~d}, J=6.5 \mathrm{~Hz}, 6-\mathrm{H}_{3}\right), 0.84\left(\mathrm{~m}, 14-\mathrm{H}_{3}\right), 0.83$ $\left(\mathrm{t}, J=6.9 \mathrm{~Hz}, 30-\mathrm{H}_{3}\right), 0.81\left(\mathrm{~d}, J=6.5 \mathrm{~Hz}, 15-\mathrm{H}_{3}\right)$; ESI-MS: $m / z 597(\mathrm{M}-\mathrm{H})^{-}$and $599(\mathrm{M}+$ $\mathrm{H})^{+}$; HR-ESI-MS: $m / z 599.4370(\mathrm{M}+\mathrm{H})^{+}$(calculated for $\mathrm{C}_{31} \mathrm{H}_{59} \mathrm{~N}_{4} \mathrm{O}_{7}, 599.4384$ ).

\subsubsection{Derivatization with MTPA}

Compound $2(1 \mathrm{mg})$ was dissolved in pyridine- $d_{5}(0.6 \mathrm{~mL})$, transferred into a NMR tube and then $(R)-(-)-\alpha$-methoxy- $\alpha$-(trifluoromethyl) phenylacetyl chloride $(10 \mu \mathrm{L})$ was added. The mixture was incubated for $2 \mathrm{~h}$ at room temperature before the measurement of ${ }^{1} \mathrm{H}, \mathrm{COSY}, \mathrm{TOCSY}, \mathrm{HSQC}$ and HMBC NMR spectra was taken. This resulted in a (S)-MTPA ester derivative: ${ }^{1} \mathrm{H}$ NMR $\left(700 \mathrm{MHz}\right.$, pyridine- $\left.d_{5}\right)$ : similar to 2 , but $\delta_{\mathrm{H}} 9.05(\mathrm{~m}, 17-\mathrm{NH}), 5.90$ $(\mathrm{m}, 23-\mathrm{H}), 4.85(\mathrm{~m}, 17-\mathrm{H}), 3.30(\mathrm{~m}, 22-\mathrm{H}), 2.35(\mathrm{~m}, 18-\mathrm{H}), 2.01\left(\mathrm{~m}, 24-\mathrm{H}_{\mathrm{a}}\right), 1.78\left(\mathrm{~m}, 24-\mathrm{H}_{\mathrm{b}}\right), 1.47$ $\left(\mathrm{m}, 25-\mathrm{H}_{2}\right), 1.27\left(\mathrm{~m}, 31-\mathrm{H}_{3}\right), 1.27\left(\mathrm{~m}, 26-\mathrm{H}_{2}\right), 1.21\left(\mathrm{~m}, 29-\mathrm{H}_{2}\right), 1.20\left(\mathrm{~m}, 27-\mathrm{H}_{2}\right), 1.18\left(\mathrm{~m}, 28-\mathrm{H}_{2}\right)$, $1.14\left(\mathrm{~m}, 19-\mathrm{H}_{3}\right), 1.03\left(\mathrm{~m}, 20-\mathrm{H}_{3}\right), 0.83\left(\mathrm{t}, J=7.3 \mathrm{~Hz}, 30-\mathrm{H}_{3}\right)$. The (R)-MTPA ester derivative was yielded analogously with $(S)-(+)-\alpha$-methoxy- $\alpha$-(trifluoromethyl) phenylacetyl chloride $(10 \mu \mathrm{L})$. The reaction was incubated in pyridine- $d_{5}(0.6 \mathrm{~mL})$ for $65 \mathrm{~h}$ at room temperature: ${ }^{1} \mathrm{H}$ NMR (700 MHz, pyridine- $\left.d_{5}\right)$ : similar to 2 , but $\delta_{\mathrm{H}} 9.22(\mathrm{~m}, 17-\mathrm{NH}), 5.87(\mathrm{~m}, 23-\mathrm{H}), 4.90$ $(\mathrm{m}, 17-\mathrm{H}), 3.28(\mathrm{~m}, 22-\mathrm{H}), 2.42(\mathrm{~m}, 18-\mathrm{H}), 1.97\left(\mathrm{~m}, 24-\mathrm{H}_{\mathrm{a}}\right), 1.67\left(\mathrm{~m}, 24-\mathrm{H}_{\mathrm{b}}\right), 1.32\left(\mathrm{~m}, 31-\mathrm{H}_{3}\right)$, $1.21\left(\mathrm{~m}, 25-\mathrm{H}_{2}, 29-\mathrm{H}_{2}\right), 1.19\left(\mathrm{~m}, 19-\mathrm{H}_{3}\right), 1.18\left(\mathrm{~m}, 26-\mathrm{H}_{2}\right), 1.13\left(\mathrm{~m}, 28-\mathrm{H}_{2}\right), 1.12\left(\mathrm{~m}, 27-\mathrm{H}_{2}\right)$, $1.10\left(\mathrm{~m}, 20-\mathrm{H}_{3}\right), 0.84\left(\mathrm{~m}, 30-\mathrm{H}_{3}\right)$. 


\subsection{Antimicrobial and Cytotoxic Activity Assays}

The antimicrobial activity was evaluated by determining the minimum inhibitory concentration (MIC) in 96-well round-bottom plates. Compounds $\mathbf{1}, \mathbf{2}$, and $\mathbf{3}$ were tested against five fungi (i.e., Candida albicans, Mucor hiemalis, Rhodotorula glutinis, Schizosaccharomyces pombe, and Wickerhamomyces anomalus) and against bacteria (Bacillus subtilis, Mycolicibacterium smegmatis, and Staphylococcus aureus (Gram-positive), as well as Acinetobacter baumanii, Chromobacterium violaceum, Escherichia coli, and Pseudomonas aeruginosa (Gram-negative)). The cell suspension of most bacteria was done in Mueller-Hinton Broth (SN X927.1, Carl Roth GmbH, Karlsruhe, Germany) and was adjusted at $\mathrm{OD}_{600} \mathrm{~nm}$ to 0.01. Mycolicibacterium smegmatis was cultured in 27H9 + ADC (Middlebrook 7H9 Broth Base + Middlebrook ADC Growth Supplement (SN M0678 + M0553, Merck, Darmstadt, Germany)) and adjusted at $\mathrm{OD}_{548} \mathrm{~nm}$ to 0.1 . The fungi were grown in MYC ( $1 \%$ bacto peptone, $1 \%$ yeast extract, $2 \%$ glycerol, $\mathrm{pH} 6.3$ ) and adjusted at $\mathrm{OD}_{548} \mathrm{~nm}$ to 0.1 . Then, $150 \mu \mathrm{L}$ of the adjusted suspension was added to all wells of a 96-well microtiter plate. In row $\mathrm{A}$, an additional $130 \mu \mathrm{L}$ of suspensions plus $20 \mu \mathrm{L}$ of the test compounds $(1 \mathrm{mg} / \mathrm{mL}$ in methanol) were added. $\mathrm{MeOH}(20 \mu \mathrm{L})$ was used as negative control, while different positive controls were used depending on the test organisms. Nystatin $(1 \mathrm{mg} / \mathrm{mL})$ was used as positive control against the fungi. Oxytetracycline $(0.1 \mathrm{mg} / \mathrm{mL}, B$ subtilis $1 \mathrm{mg} / \mathrm{mL})$ was used for the bacteria, except for Ac. baumanii, M. smegmatis, and P. aeruginosa, against which cibrobay $(0.25 \mathrm{mg} / \mathrm{mL})$, kanamycin $(0.1 \mathrm{mg} / \mathrm{mL})$, and gentamycin $(0.1 \mathrm{mg} / \mathrm{mL})$ were used, respectively. Then, starting from row A, $150 \mu \mathrm{L}$ of the suspension were transferred to the next row, and $150 \mu \mathrm{L}$ transferred to the following row. The remaining $150 \mu \mathrm{L}$ after row $\mathrm{H}$ were discarded. This resulted in a serial dilution of the test compounds, ranging from $66.7 \mu \mathrm{g} / \mathrm{mL}$ in row A to $0.52 \mu \mathrm{g} / \mathrm{mL}$ in row $\mathrm{H}$. The assay was incubated overnight at $800 \mathrm{rpm}$ on a microplate shaker. The temperature was chosen due to the microorganisms. They were grown at $30^{\circ} \mathrm{C}$, except M. smegmatis, E. coli, and $P$. aeruginosa which were grown at $37^{\circ} \mathrm{C}$. The lowest concentration of the compounds preventing visible growth of the test organism was recorded as the MIC.

The cytotoxicity of compounds $\mathbf{1}, \mathbf{2}$, and $\mathbf{3}$ were tested against the two mammalian cell lines KB 3.1 (human endo-cervical adenocarcinoma) and L929 (mouse fibroblasts) in a 96-well plate. The compounds were dissolved as described in the previous section and epothilone B was used as the positive control. The cell lines were incubated with a serial dilution assay of the compounds (final range: 37 to $0.6 \times 10^{-3} \mu \mathrm{g} / \mathrm{mL}$ ) at $37^{\circ} \mathrm{C}$ with $10 \%$ $\mathrm{CO}_{2}$ in Gibco TM Dulbecco's Modified Eagle Medium (SN 61965026, Thermo Fisher Scientific, Waltham, MA, USA) supplemented with 10\% Fetal Bovine Serum (SN 10500064, Thermo Fisher Scientific). After five days the cells were stained with 3-(4,5-dimethyl-2-thiazolyl)-2,5diphenyl-2H-tetrazolium bromide (MTT, (M2128, Sigma-Aldrich, Deisenhofen, Germany)). The dye is converted to its purple derivative by living cells. The intensity of the purple derivative in the relation to the cells without additive ( $100 \%$ viability) was quantified for each concentration of the test compound. For the quantification, a microplate reader with $595 \mathrm{~nm}$ was used to calculate the percentage of the cell viability. From these results, the half-maximum inhibitory concentration $\left(\mathrm{IC}_{50}\right)$ in $\mu \mathrm{M}$ was calculated.

\section{Results}

\subsection{Molecular Phylogeny and Taxonomy}

The lengths of the individual alignments used in the combined dataset were $681 \mathrm{bp}$ (ITS), $894 \mathrm{bp}$ (LSU), $984 \mathrm{bp}$ ( $r p b 2)$, and $618 \mathrm{bp}$ (tub2), being the final total alignment of $3177 \mathrm{bp}$. The Maximum Likelihood tree obtained from the RAxML analysis of the combined dataset, including RAxML bootstrap support (BS) and Bayesian posterior probability at the nodes, is shown in Figure 1. For the BI analysis, the GTR + I + G model was selected for all partitions. The RAxML tree topology agreed with the topology of the tree generated by the BI analysis. The combined phylogenetic tree (Figure 1) showed seven main clades representing the families Chaetomiaceae, Diplogelasinosporaceae, Lasiosphaeriaceae, Naviculisporaceae, Podosporaceae, Schizotheciaceae, and Sordariaceae. The ex-type strain of 
Apiosordaria vermicularis was located in the family Schizotheciaceae, far from the Triangularia clade in Podosporaceae, where the type species of Apiosordaria (now T. verruculosa) is placed. Apiosordaria vermicularis formed a well-supported clade (79\% bs/0.98 pp) with Echria spp. and Rinaldiella pentagonospora, but showed enough phylogenetic distance to propose it as the type species of the new genus Morinagamyces, as Morinagamyces vermicularis.

\section{Morinagamyces Y. Marín and Stchigel, gen. nov. MycoBank MB839453.}

Type species: Morinagamyces vermicularis (Morinaga, Minoura and Udagawa) Y. Marín and Stchigel.

Etymology: Named in honor of the mycologist Tsutomu Morinaga, who collected and isolated the ex-type strain and introduced the basionym.

Ascomata non-ostiolate, scattered, semi-immersed to immersed, brownish black to black, opaque, globose to subglobose, glabrous or covered on upper exposed part with long, straight or flexuous, brown, septate, unbranched or branched, smooth-walled, hypha-like hairs; ascomatal wall brown to dark brown, membranaceous to coriaceous, three-layered; outer layer of textura intricata; middle layer composed of thin-walled, yellow brown to brown angular cells; inner layer composed of hyaline, flattened cells. Paraphyses filiform to ventricose, hyaline. Asci unitunicate, eight-spored, long cylindrical, often curved or sinuous, disposed in a basal fascicle, rounded apex, apical ring indistinct in the apex, non-amyloid, long-stipitate. Ascospores uniseriate, at first one-celled, hyaline, cylindricalellipsoidal, later becoming transversely uniseptate; upper cells dark olivaceous brown to dark brown, ovate to broadly ellipsoidal, truncate at base, rounded or slightly acuminate at apex, with walls ornamented by numerous, stiff warts, with a germ pore in apex; lower cell hyaline to pale brown, cylindrical to long triangular, frequently 1-septate, smoothwalled. Asexual morph of two types: (1) Conidiophores indistinguishable from the hyphae. Conidiogenous cells phialidic, integrated to hyphae, cylindrical, with a terminal collarette. Conidia hyaline, subglobose to ovate, smooth-walled, gathering in a globose, slimy mass; (2) Conidia holoblastic, borne along the sides of hyphae, sessile or short-stipitate, hyaline, pyriform to clavate, truncate at base, rounded apex, smooth-walled.

Notes: Echinopodospora vermicularis was introduced by Morinaga et al. to accommodate a fungus from soil in Hong Kong characterized by the production of non-ostiolate ascomata and ascospores with a warted upper cell [38]. Subsequently, it was transferred to Apiosordaria, when the genus Echinopodospora was synonymized with Apiosordaria based on their morphological similarities [39]. However, the phylogenetic data demonstrated that this species represents a new lineage in the recently introduced family Schizotheciaceae, and consequently the genus Morinagamyces was introduced. The main distinctive feature of this new genus is the presence of two different kinds of asexual morphs, i.e., cladorrhinumand chrysosporium-like. This particular feature has only been reported in another species of the Sordariales, A. effusa [38], which has never been studied with molecular data, and its taxonomic position remains unresolved. Surprisingly, the cladorrhinum-like asexual morph is distinctive of the three genera belonging to the family Podosporaceae, i.e., Cladorrhinum, Podospora, and Triangularia, as it is not observed in any other families of the Sordariales. 


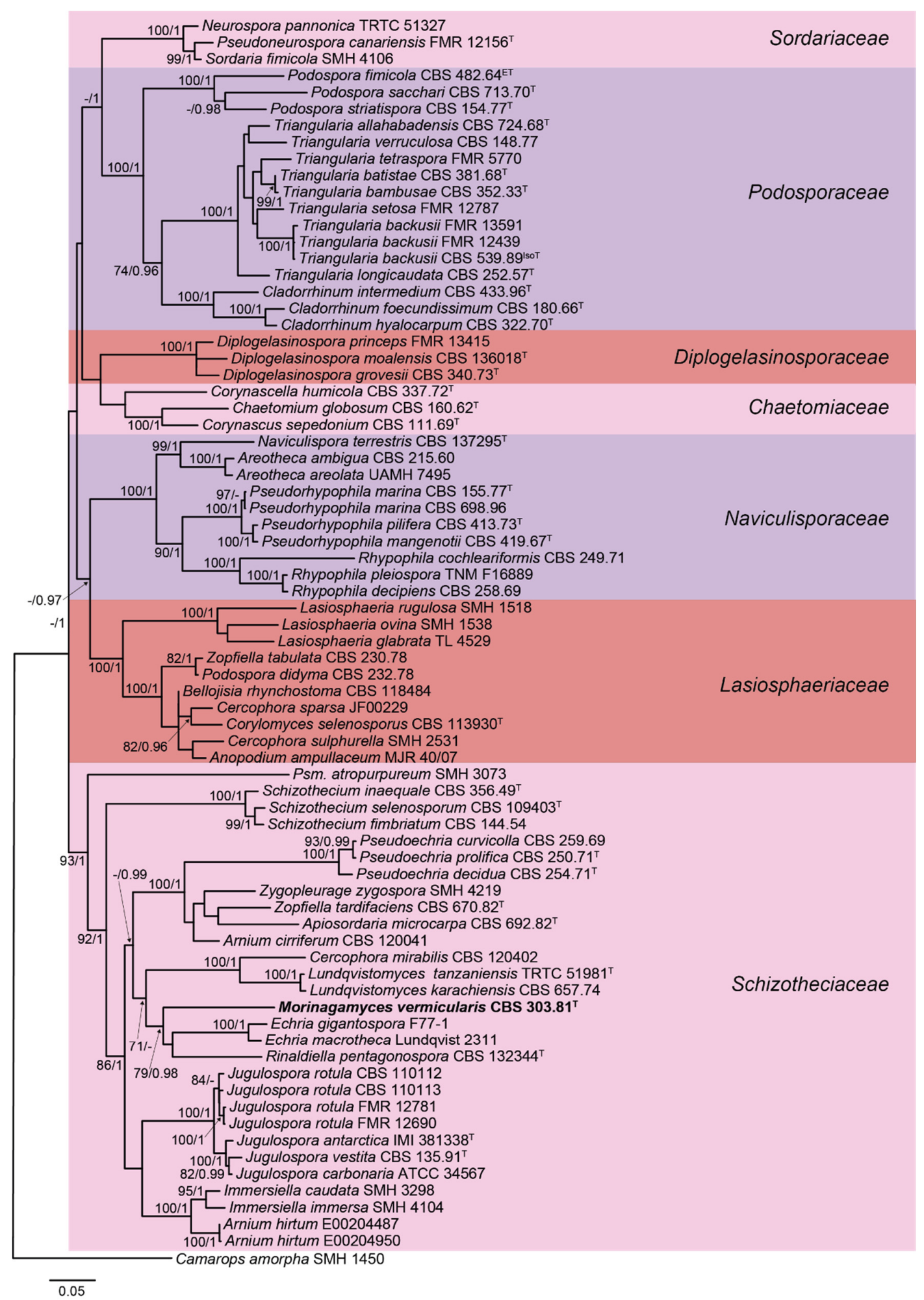

Figure 1. RAxML phylogram obtained from the combined sequences of the internal transcribed spacer region (ITS), the nuclear rDNA large subunit (LSU), and fragments of ribosomal polymerase II subunit 2 ( $r p b 2$ ) and $\beta$-tubulin (tub2) genes of selected strains belonging to the families Chaetomiaceae, Diplogelasinosporaceae, Lasiosphaeriaceae, Naviculisporaceae, Podosporaceae, Schizotheciaceae, and Sordariaceae. Camarops amorpha was used as outgroup. Bootstrap support values $\geq$ 70 /Bayesian posterior probability scores $\geq 0.95$ are indicated along branches. Branch lengths are proportional to distance. Novelty is indicated in bold. Ex-epitype, ex-isotype, and ex-type strains of the different species are indicated with ET, IsoT and $^{\mathrm{T}}$, respectively. 
The closest related genera to Morinagamyces are Echria and Rinaldiella. However, the later genera have not been reported to produce asexual morphs and they are characterized by the production of ostiolate ascomata, while Morynagamyces produces non-ostiolate ones. Echria can be easily distinguished from the other two genera by production of onecelled roughened or smooth-walled ascospores (two-celled and warted in the other two genera) [19]. Morinagamyces and Rinaldiella produce two-celled warted ascospores, but the upper cell is five-angled in side view in Rinaldiella [27], while it is ovate to broadly ellipsoidal in Morinagamyces.

\section{Morinagamyces vermicularis (Morinaga, Minoura and Udagawa) Y. Marín and Stchigel, comb. nov. MycoBank MB839454.}

Basionym: Echinopodospora vermicularis Morinaga, Minoura and Udagawa, Trans. Mycol. Soc. Japan 19: 138. 1978.

Synonym: Apiosordaria vermicularis (Morinaga, Minoura and Udagawa) J.C. Krug, Udagawa and Jeng, Mycotaxon 17: 547. 1983.

\subsection{Isolation and Structure Elucidation of Secondary Metabolites}

Morinagadepsin (1) was isolated as a white powder. Its molecular formula of $\mathrm{C}_{31} \mathrm{H}_{56} \mathrm{~N}_{4} \mathrm{O}_{6}$ was derived from its HR-ESI-MS peak observed at $m / z$ 581.4271, implying six degrees of unsaturation. ${ }^{1} \mathrm{H}$ and HSQC (Heteronuclear single-quantum correlation spectroscopy) NMR spectra measured in DMSO- $d_{6}$ specified the presence of nine methyls, seven methylenes, and nine methines, of which four were bound to nitrogen and one bound to oxygen, in addition to four exchangeable protons bound to heteroatoms. The ${ }^{13} \mathrm{C}-\mathrm{NMR}$ spectrum indicated the presence of five carbonyls. By COSY (correlation spectroscopy), TOCSY (total correlation spectroscopy) and intra-residue HMBC (heteronuclear multiple-bond correlation spectroscopy) correlations, alanine (Ala), valine (Val), and two leucine (Leu-1 and Leu-2), as well as 3-hydroxy-2-methyldecanoic acid (HMDA) residues were assembled (see Figure $2 \mathrm{~b}$ ). The sequence of entities was assigned by inter-residue ${ }^{1} \mathrm{H},{ }^{13} \mathrm{C} \mathrm{HMBC}$ correlations (Figure $2 \mathrm{~b})$. The low field shift of $23 \mathrm{H}\left(\delta_{\mathrm{H}} 4.92\right)$ indicated an ester linkage at this position, which was confirmed by the ${ }^{1} \mathrm{H},{ }^{13} \mathrm{C}$ HMBC correlation of $23-\mathrm{H}$ to $\mathrm{C}-1$, establishing the planar depsipeptidal structure of $\mathbf{1}$.

a)

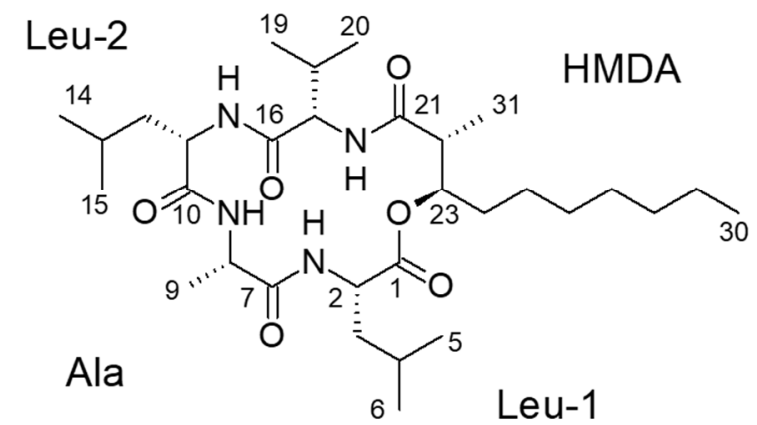

b)

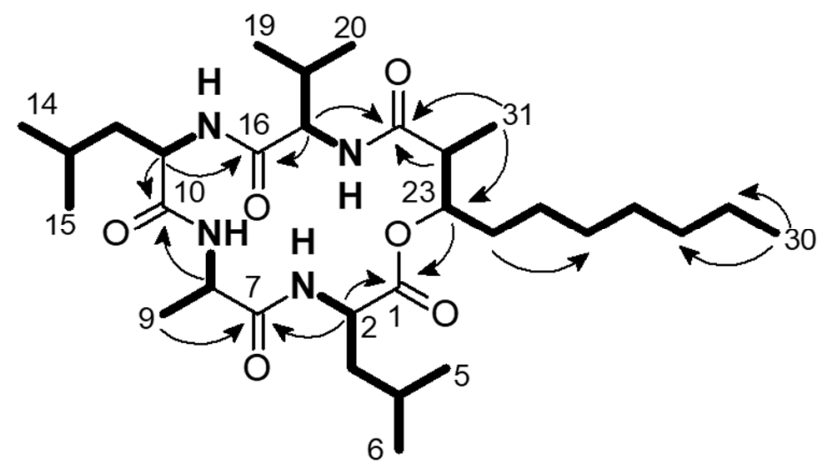

Figure 2. (a) Structure of morinagadepsin 1. (b) selected ${ }^{1} \mathrm{H},{ }^{1} \mathrm{H}$ COSY (bold lines) and ${ }^{1} \mathrm{H},{ }^{13} \mathrm{C}$ HMBC (black arrows) correlations of $\mathbf{1}$.

After complete hydrolysis and derivatization with FDAA, we observed L-Leu, LVal, and L-Ala according to Marfey's method [36]. Thus, C-2, C-8, C-11, and C-17 are $S$-configurated. The relative configurations of the chiral centers C-22/C-23 in HMDA was determined by $J$-based configurational analysis using ${ }^{3} J_{\mathrm{HH}},{ }^{2} J_{\mathrm{CH}},{ }^{3} J_{\mathrm{CH}}$ and ROESY correlations (Figure 3) as $22 R^{*}, 23 R^{*}$. Necessary proton-carbon coupling constants were obtained from a HSQC-Hecade NMR spectrum (Figure S10), except ${ }^{3} \mathrm{~J}(\mathrm{H} 23, \mathrm{C} 21)=6.6 \mathrm{~Hz}$, which was extracted from a J-HMBC NMR experiment (Figure S11) [40]. 


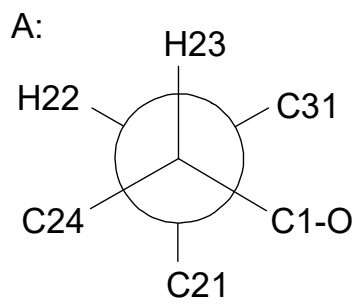

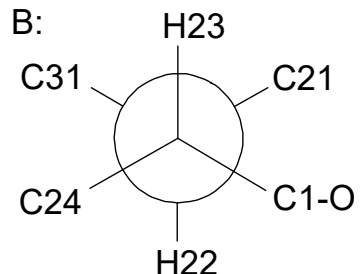

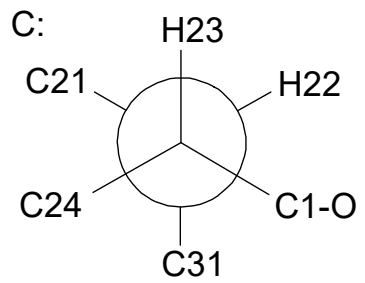

$\mathrm{H} 22-\mathrm{H} 23$ small

H22-C23 small

H22-C24 small

H23-C31 small

H23-C21 large

$\mathrm{H} 22-\mathrm{H} 23$ large

$\mathrm{H} 22-\mathrm{C} 23$ large

H22-C24 small

H23-C31 small

H23-C21 small

$\mathrm{H} 22-\mathrm{H} 23$ small

H22-C23 large

H22-C24 large

H23-C31 large

H23-C21 small
D:

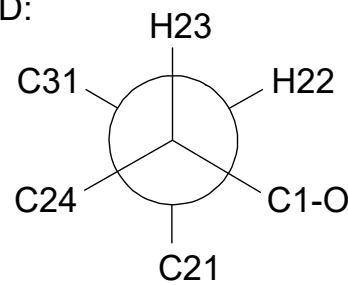

$\mathrm{H} 22-\mathrm{H} 23$ small

$\mathrm{H} 22-\mathrm{C} 23$ large

H22-C24 large

H23-C31 small

H23-C31 large

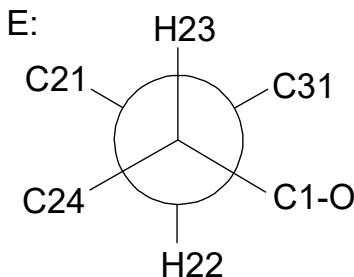

$\mathrm{H} 22-\mathrm{H} 23$ large

$\mathrm{H} 22-\mathrm{C} 23$ large

H22-C24 small

H23-C31 small

H23-C21 small

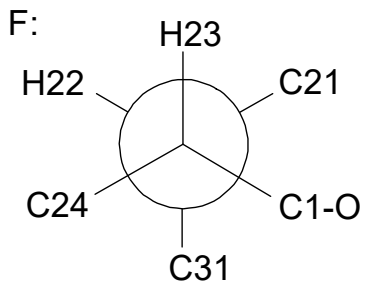

$\mathrm{H} 22-\mathrm{H} 23$ small

H22-C23 small

H22-C24 small

H23-C31 large

H23-C21 small

Figure 3. J-based analysis of six hypothetical rotamers with 22S,23S (A-C) and 22S,23R (D-F) configuration to determine the stereochemistry of $\mathbf{1}$. Expected couplings contrary (shown in red) to the observed ones $\left({ }^{3} \mathrm{~J}(\mathrm{H} 22, \mathrm{H} 23)=4.8 \mathrm{~Hz} ;{ }^{2} \mathrm{~J}(\mathrm{H} 22, \mathrm{C} 23)=\right.$ $\left.2.2 \mathrm{~Hz} ;{ }^{3} \mathrm{~J}(\mathrm{H} 22, \mathrm{C} 24)=1.0 \mathrm{~Hz} ;{ }^{2} \mathrm{~J}(\mathrm{H} 23, \mathrm{C} 31)=2.6 \mathrm{~Hz} ;{ }^{3} \mathrm{~J}(\mathrm{H} 23, \mathrm{C} 21)=6.6 \mathrm{~Hz}\right)$ exclude all configurations except A. This rotamer is confirmed by ROESY correlations between $23-\mathrm{H} / 22-\mathrm{H}, 23-\mathrm{H} / 31-\mathrm{H}_{3}, 24-\mathrm{H}_{\mathrm{a}} / \mathrm{b} / 22-\mathrm{H}$, and $31-\mathrm{H}_{3} / 3-\mathrm{H}_{\mathrm{b}}$.

Finally, the absolute configuration of the HMDA subunit was determined by the derivatization of the methanolysis product with $S$ - and R-MTPA according to Mosher's method. The pattern of $\Delta \delta^{\mathrm{SR}}$ values (see Figure 4) with negative values for 17-NH, $17-\mathrm{H}$, $18-\mathrm{H}, 19-\mathrm{H}_{3}, 20-\mathrm{H}_{3}$, and $31-\mathrm{H}_{3}$, and positive ones for $24-\mathrm{H}_{2}$ to $29-\mathrm{H}_{2}$, is diagnostic for a $23 \mathrm{R}$ configuration [41].

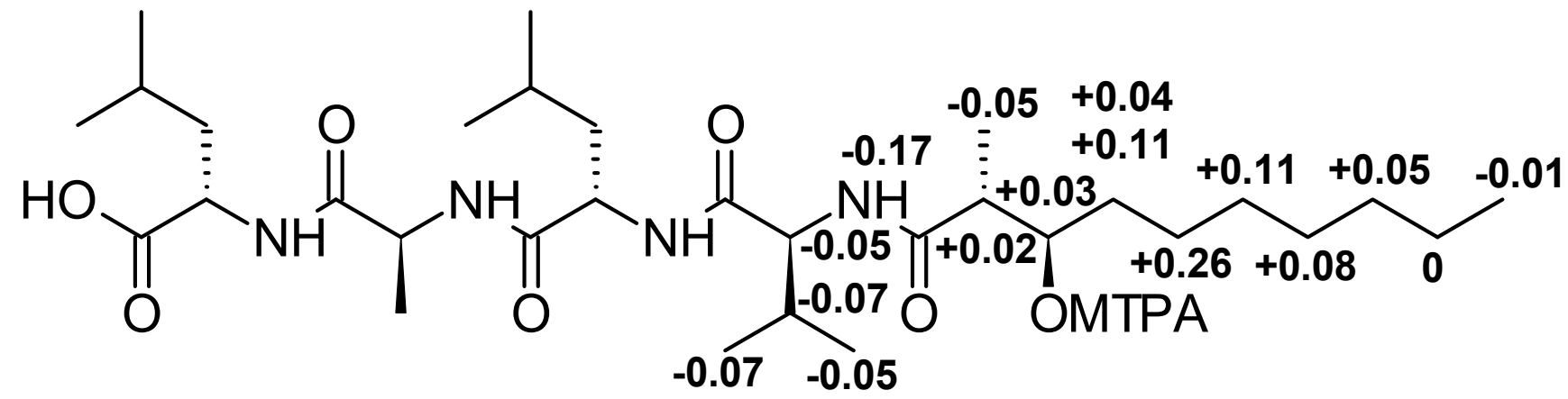

Figure 4. $\Delta \delta^{\mathrm{SR}}$ vvalues in ppm for the C-23-MTPA esters of 2 in pyridin- $\mathrm{d}_{5}$.

\subsection{Biological Activities}

Compounds 1 and 2 were not active against the microorganisms tested in the serial dilution assay. Compound $\mathbf{3}$ showed weak activity against B. subtilis and $M u$. hiemalis (Table 3). 
Table 3. Minimum inhibitory concentration (MIC, $\mu \mathrm{g} / \mathrm{mL}$ ) of 1-3 against bacterial and fungal test organisms.

\begin{tabular}{lccccc}
\hline \multicolumn{1}{c}{ Test Organism } & Strain Number & $\mathbf{1}$ & $\mathbf{2}$ & $\mathbf{3}$ & Positive Control \\
\hline Bacillus subtilis & DSM 10 & - & - & 66.6 & $8.30^{\mathrm{O}}$ \\
Mycolicibacterium smegmatis & ATCC 700084 & - & - & - & $1.70^{\mathrm{K}}$ \\
Staphylococcus aureus & DSM 346 & - & - & - & $0.83^{\mathrm{O}}$ \\
Acinetobacter baumanii & DSM 30008 & - & - & - & $0.53^{\mathrm{C}}$ \\
Chromobacterium violaceum & DSM 30191 & - & - & - & $0.83^{\mathrm{O}}$ \\
Escherichia coli & DSM 1116 & - & - & - & $1.70^{\mathrm{O}}$ \\
Pseudomonas aeruginosa & DSM 19882 & - & - & - & $0.42^{\mathrm{G}}$ \\
Mucor hiemalis & DSM 2656 & - & - & 66.6 & $2.10^{\mathrm{N}}$ \\
Candida albicans & DSM 1665 & - & - & - & $4.20^{\mathrm{N}}$ \\
Rhodotorula glutinis & DSM 10134 & - & - & - & $1.00^{\mathrm{N}}$ \\
Schizosaccharomyces pombe & DSM 70572 & - & - & - & $4.20^{\mathrm{N}}$ \\
Wickerhamomyces anomala & DSM 6766 & - & - & - & $4.20^{\mathrm{N}}$ \\
\hline
\end{tabular}

ATCC: American Type Culture Collection, Manassas, VA, USA; DSM: Leibniz-Institut DSMZ—German Collection of Microorganisms and Cell Cultures $\mathrm{GmbH}$, Braunschweig, Germany. ${ }^{\mathrm{C}}$ cibrobay, $\mathrm{G}$ gentamicin, $\mathrm{K}$ kanamycin, $\mathrm{N}$ nystatin, and ${ }^{\mathrm{O}}$ oxytetracycline. -: no inhibition observed under test conditions.

Only compound 1 showed weak cytotoxic activity against the mammalian cell lines tested, while compound 3 was only weakly cytotoxic against the L929 cell line, and compound 2 did not have any activity (Table 4).

Table 4. Cytotoxicity of 1-3 against mammalian cell lines (half maximal inhibitory concentrations $\left.\left(\mathrm{IC}_{50}\right): \mu \mathrm{M}\right)$.

\begin{tabular}{cccccc}
\hline \multirow{2}{*}{ Cell Line } & \multirow{2}{*}{ Number $^{\mathbf{1}}$} & \multicolumn{5}{c}{ IC $_{\mathbf{5 0}}[\mu \mathrm{M}]$} \\
\cline { 3 - 6 } & & $\mathbf{1}$ & $\mathbf{2}$ & $\mathbf{3}$ & Epothilone B* $^{*}$ \\
\hline HeLa KB 3.1 & ACC 158 & 37.2 & - & - & 0.00003 \\
Mouse fibroblast L929 & ACC 2 & 13.7 & - & 34.9 & 0.00051 \\
\hline
\end{tabular}

-: no inhibition observed under test conditions. ${ }^{1}$ ACC: Leibniz-Institut DSMZ-German Collection of Microorganisms and Cell Cultures GmbH, Braunschweig, Germany. * positive control (1 mg/mL).

\section{Discussion}

The genus Apiosordaria, as well as other lasiosphaeriaceous genera, such as Cercophora, Podospora, and Zopfiella, resulted in a polyphyletic clade. Encompassing species scattered among the order Sordariales $[4,5,12,20,28,32]$. The main problem is that the traditional classification of the lasiosphaeriaceous taxa was based predominantly on the ascospore morphology, but this was found to be an extremely homoplastic character [12]. Apiosordaria was recently synonymized with Triangularia, located in the Podosporaceae, as the type species $A$. verruculosa formed a monophyletic clade with the type species of this later genus, T. bambusae, being consequently proposed the new combination T. backusii and T. verruculosa [4]. Subsequently, A. sacchari and A. striatispora were also transferred to Triangularia, whereas $A$. antarctica, $A$. globosa, $A$. hispanica, and $A$. vestita have been transferred to Jugulospora, phylogenetically located in the Schizotheciaceae [5]. However, a high number of Apiosordaria spp. remain in an uncertain taxonomic placement, as in the case of A. microcarpa (see Figure 1). In order to get a more natural classification of these species, the new genus Morinagamyces is introduced to accommodate $A$. vermicularis, which has proven to be an independent lineage in the Schizotheciaceae. This genus differs from the other taxa of the family, and even the order Sordariales, by the production of two types of asexual morphs, i.e., cladorrhinum- and chrysosporium-like. This characteristic was also observed in A. effusa [38]. Therefore, further studies will be needed to verify if this species also belongs to the genus Morinagamyces.

Morinagadepsin (1) belongs to the large class of depsipeptides, compounds containing both amide and ester bonds, which are widely distributed in nature. They have been 
isolated from plants, sponges and lower animals, cyanobacteria, bacteria, and fungi, with bioactivities ranging from antimicrobial, nematicidal, antiviral, and cytotoxic/cytostatic, to immunosuppressive and other pharmacologically important properties [42]. Fungal depsipeptides have been reported from many fungal genera, and it would lead too far to mention them all here. Some prominent examples are shown in Figure S23 (Supplementary Information). The nematicidal cyclodepsipeptide PF1022-A (Figure S23d), which has given rise to the marketed antiparasitic agent emodepside, had originally been discovered from an endophytic fungus associated with the tea plant, and only recently the affinities of the producer strain to the genus Rosellinia (Xylariaceae) were established [43]. The related cyclic hexadepsipeptide beauvericin (Figure S23a) probably acts as pathogenicity factor in the insect pathogenic Beauveria and Isaria species, and was also found in the genus Fusarium $[44,45]$. Verlamelin (Figure S23g) is another known depsipeptide with antifungal properties, produced by Simplicillium lamellicola (syn. Verticillium lamellicola) [46] and was eventually under development as antimycotic. Morinagadepsin belongs to the subgroup of cyclic pentadepsipeptides, which have been isolated from the genera Acremonium, Alternaria, Fusarium, Hapsidospora, and Penicillium [47]. Its hallmark is the presence of a 3-hydroxy-2-methyldecanoic acid (HMDA) moiety. HMDA has previously been detected as part of emericellamides C and D (Figure S23b) produced by Aspergillus nidulans [48], the lipopeptaibol trichopolyn V (Figure S23f) from Trichoderma polysporum [49], hapalosin (Figure S23c) from the cyanobacterium Hapalasiphon welwitschii [50], and the globomycin derivative SF-1902 A $\mathrm{A}_{4 \mathrm{a}}$ (Figure S23e) from the bacterium Streptomyces hygroscopicus [51]. In the case of globomycin and its derivatives, the $\beta$-hydroxy- $\alpha$-methyl carboxylic acid greatly contributes to the antibacterial activity [52]. Compound $\mathbf{1}$ did not show any activity against any microorganisms tested in the present study, but it was weakly cytotoxic against the two cell lines tested, while compound 2, which is the linear peptide obtained from the partial hydrolysis of $\mathbf{1}$, did not show antimicrobial or cytotoxic activity.

The other compound isolated from M. vermicularis was chaetone B (3). This compound was previously isolated from a strain of Chaetomium isolated from submerged woody substrate in fresh water [35], which is another member of the order Sordariales. Shen et al. [35] observed moderate activity of this compound against S. aureus in a standard disk assay. However, this compound did not show activity against this bacterium in our serial dilution assay. It showed weak bioactivity against the Gram-positive bacterium B. subtilis, and the fungus $\mathrm{Mu}$. hiemalis. Compound $\mathbf{3}$ was also weakly cytotoxic against the L929 cell line.

Supplementary Materials: The following are available online at https://www.mdpi.com/article/ 10.3390/microorganisms9061191/s1, Figure S1: HPLC-ESI-MS spectrum of morinagadepsin (1) in positive and negative; Figure S2: HPLC-HR-ESI-MS spectrum of morinagadepsin (1) in positive mode; Figure S3: ${ }^{1} \mathrm{H}$ NMR spectrum (700 MHz, DMSO- $d_{6}$ ) of morinagadepsin (1); Figure S4: ${ }^{13} \mathrm{C}$ NMR spectrum (175 MHz, DMSO- $\left.d_{6}\right)$ of morinagadepsin (1); Figure S5: COSY NMR spectrum (700 MHz, DMSO- $d_{6}$ ) of morinagadepsin (1); Figure S6: HSQC NMR spectrum (700 MHz, DMSO- $d_{6}$ ) of morinagadepsin (1); Figure S7: HMBC NMR spectrum (700 MHz, DMSO- $d_{6}$ ) of morinagadepsin (1); Figure S8: ROESY NMR spectrum (700 MHz, DMSO- $d_{6}$ ) of morinagadepsin (1); Figure S9: J-res NMR spectrum $\left(700 \mathrm{MHz}\right.$, DMSO- $d_{6}$ ) of morinagadepsin (1); Figure S10: Sections from the HSQC-Hecade NMR spectrum $\left(700 \mathrm{MHz}\right.$, DMSO- $d_{6}$ ) of morinagadepsin (1); Figure S11: J-HMBC NMR spectrum (700 MHz, DMSO- $d_{6}$ ) of morinagadepsin (1); Figure S12: HPLC-ESI-MS spectrum of 2 in positive and negative mode; Figure S13: HPLC-HR-ESI-MS spectrum of 2 in positive mode; Figure S14: ${ }^{1} \mathrm{H}$ NMR spectrum $\left(700 \mathrm{MHz}\right.$, pyridine- $\left.d_{5}\right)$ of 2 ; Figure $\mathrm{S} 15:{ }^{13} \mathrm{C}$ NMR spectrum (175 MHz, pyridine$\left.d_{5}\right)$ of 2; Figure S16: HSQC NMR spectrum (700 MHz, pyridine- $\left.d_{5}\right)$ of 2; Figure S17: COSY NMR spectrum ( $700 \mathrm{MHz}$, pyridine- $d_{5}$ ) of 2; Figure S18: HMBC NMR spectrum (700 MHz, pyridine- $d_{5}$ ) of 2; Figure S19: HSQC NMR spectrum (700 MHz, pyridine- $\left.d_{5}\right)$ of the S-MTPA-ester of 2; Figure S20: HSQC NMR spectrum $\left(700 \mathrm{MHz}\right.$, pyridine- $\left.d_{5}\right)$ of the R-MTPA-ester of 2; Figure S21: HPLC-ESI-MS spectrum of chaetone B (3) in positive and negative mode; Figure S22: HPLC-HR-ESI-MS spectrum of chaetone B (3) in positive mode; and Figure S23: Chemical structures of some known cyclodepsipeptides. 
Author Contributions: Conceptualization, F.S. and Y.M.-F.; methodology, F.S., K.H., and Y.M.-F.; software, M.S.; formal analysis, F.S., K.H., and Y.M.-F.; investigation, F.S., K.H., and Y.M.-F.; resources, A.M.S. and M.S.; data curation, F.S. and Y.M.-F.; writing-original draft preparation, F.S., K.H., and Y.M.-F.; writing-review and editing, A.M.S. and M.S.; visualization, F.S., K.H., and Y.M.-F. All authors have read and agreed to the published version of the manuscript.

Funding: Yasmina Marin-Felix is grateful for the postdoctoral stipendium received from Alexandervon-Humboldt Foundation, Germany.

Institutional Review Board Statement: Not applicable.

Informed Consent Statement: Not applicable.

Data Availability Statement: The DNA sequences are deposited in GenBank (https://www.ncbi. nlm.nih.gov/genbank/) and all other relevant data are included in the Supplementary Information.

Acknowledgments: The authors wish to thank Christel Kakoschke and Kirsten Harmrolfs for recording the NMR spectra, and Wera Collisi for conducting the bioassays. We would also like to thank Takayuki Aoki (National Agriculture and Food Research Organization, Tsukuba, Japan) for providing the literature used in the present study.

Conflicts of Interest: The authors declare no conflict of interest.

\section{References}

1. von Arx, J.A.; Gams, W. Über Pleurage verruculosa und die zugehörige Cladorrhinum-Konidienform. Nova Hedwigia 1967, 13, 199-208.

2. Guarro, J.; Cano, J. The genus Triangularia. Trans. Br. Mycol. Soc. 1988, 91, 587-591. [CrossRef]

3. Guarro, J.; Gene, J.; Stchigel, A.M.; Figueras, M.J. Atlas of Soil Ascomycetes; CBS Biodiversity Series No. 10; CBS-KNAW Fungal Biodiversity Centre: Utrecht, The Netherlands, 2012.

4. Wang, X.W.; Bai, F.Y.; Bensch, K.; Meijer, M.; Sun, B.D.; Han, Y.F.; Crous, P.W.; Samson, R.A.; Yang, F.Y.; Houbraken, J. Phylogenetic re-evaluation of Thielavia with the introduction of a new family Podosporaceae. Stud. Mycol. 2019, 93, 155-252. [CrossRef] [PubMed]

5. Marin-Felix, Y.; Miller, A.N.; Cano-Lira, J.F.; Guarro, J.; García, D.; Stadler, M.; Huhndorf, S.M.; Stchigel, A.M. Re-evaluation of the order Sordariales: Delimitation of Lasiosphaeriaceae s. str., and introduction of the new families Diplogelasinosporaceae, Naviculisporaceae and Schizotheciaceae. Microorganisms 2020, 8, 1430. [CrossRef]

6. Guo, Q.F.; Yin, Z.H.; Zhang, J.J.; Kang, W.Y.; Wang, X.W.; Ding, G.; Chen, L. Chaetomadrasins A and B, two new cytotoxic cytochalasans from desert soil-derived fungus Chaetomium madrasense 375. Molecules 2019, 24, 3240. [CrossRef] [PubMed]

7. Noumeur, S.R.; Teponno, R.B.; Helaly, S.E.; Wang, X.-W.; Harzallah, D.; Houbraken, J.; Crous, P.W.; Stadler, M. Diketopiperazines from Batnamyces globulariicola, gen. \& sp. nov. (Chaetomiaceae), a fungus associated with roots of the medicinal plant Globularia alypum in Algeria. Mycol. Progr. 2020, 19, 589-603.

8. Shao, L.; Marin-Felix, Y.; Surup, F.; Stchigel, A.M.; Stadler, M. Seven new cytotoxic and antimicrobial xanthoquinodins from Jugulospora vestita. J. Fungi 2020, 6, 188. [CrossRef]

9. Harms, K.; Milic, A.; Stchigel, A.M.; Stadler, M.; Surup, F.; Marin-Felix, Y. Three new derivatives of zopfinol from Pseudorhypophila mangenotii gen. et comb. nov. J. Fungi 2021, 7, 181. [CrossRef]

10. White, T.J.; Bruns, T.D.; Lee, S.; Taylor, J. Amplification and direct sequencing of fungal ribosomal genes for phylogenetics. In PCR Protocols: A Guide to Methods and Applications; Gelfand, M., Sninsky, J.I., White, T.J., Eds.; Academic Press: New York, NY, USA, 1990; pp. 315-322.

11. Vilgalys, R.; Hester, M. Rapid genetic identification and mapping of enzymatically amplified ribosomal DNA from several species of Cryptococcus. J. Bacteriol. 1990, 172, 4238-4246. [CrossRef]

12. Miller, A.N.; Huhndorf, S. Multi-gene phylogenies indicate ascomal wall morphology is a better predictor of phylogenetic relationships than ascospore morphology in the Sordariales (Ascomycota, Fungi). Mol. Phylogen. Evol. 2005, 35, 60-75. [CrossRef]

13. Katoh, K.; Standley, D.M. MAFFT multiple sequence alignment software v. 7: Improvements in performance and usability. Mol. Biol. Evol. 2013, 30, 772-780. [CrossRef]

14. Kumar, S.; Stecher, G.; Li, M.; Knyaz, C.; Tamura, K. MEGA X: Molecular Evolutionary Genetics Analysis across Computing Platforms. Mol. Biol. Evol. 2018, 35, 1547-1549. [CrossRef] [PubMed]

15. Mason-Gamer, R.; Kellogg, E. Testing for phylogenetic conflict among molecular data sets in the tribe Triticeae (Gramineae). Syst. Biol. 1996, 45, 524-545. [CrossRef]

16. Wiens, J.J. Testing phylogenetic methods with tree congruence: Phylogenetic analysis of polymorphic morphological characters in phrynosomatid lizards. Syst. Biol. 1998, 47, 427-444. [CrossRef]

17. Nylander, J.A.A. MrModeltest v2.2. Uppsala: Distributed by the author; Evolutionary Biology Centre, Uppsala University: Uppsala, Sweden, 2004. 
18. Alfaro, M.E.; Zoller, S.; Lutzoni, F. Bayes or bootstrap. A simulation study comparing the performance of Bayesian Markov chainMonte Carlo sampling and bootstrapping in assessing phylogenetic concordance. Mol. Biol. Evol. 2003, 20, 255-266. [CrossRef]

19. Kruys, Å.; Huhndorf, S.M.; Miller, A.N. Coprophilous contributions to the phylogeny of Lasiosphaeriaceae and allied taxa within Sordariales (Ascomycota, Fungi). Fungal Divers. 2015, 70, 101-113. [CrossRef]

20. Cai, L.; Jeewon, R.; Hyde, K.D. Phylogenetic evaluation and taxonomic revision of Schizothecium based on ribosomal DNA and protein coding genes. Fungal Divers. 2005, 19, 1-21.

21. Miller, A.N.; Huhndorf, S.M. Using phylogenetic species recognition to delimit species boundaries within Lasiosphaeria. Mycologia 2004, 96, 1106-1127. [CrossRef]

22. Réblová, M. Bellojisia, a new sordariaceous genus for Jobellisia rhynchostoma and a description of Jobellisiaceae fam. nov. Mycologia 2008, 100, 893-901. [CrossRef]

23. Vu, D.; Groenewald, M.; de Vries, M.; Gehrmann, T.; Stielow, B.; Eberhardt, U.; Al-Hatmi, A.; Groenewald, J.Z.; Cardinali, G.; Houbraken, J.; et al. Large-scale generation and analysis of filamentous fungal DNA barcodes boosts coverage for kingdom Fungi and reveals thresholds for fungal species and higher taxon delimitation. Stud. Mycol. 2019, 92, 135-154. [CrossRef]

24. Wang, X.-W.; Lombard, L.; Groenewald, J.Z.; Li, J.; Videira, S.I.R.; Samson, R.A.; Liu, X.-Z.; Crous, P.W. Phylogenetic reassessment of the Chaetomium globosum species complex. Persoonia 2016, 36, 83-133. [CrossRef] [PubMed]

25. Stchigel, A.M.; Cano, J.; Miller, A.N.; Calduch, M.; Guarro, J. Corylomyces: A new genus of Sordariales from plant debris in France. Mycol. Res. 2006, 110, 1361-1368. [CrossRef]

26. Greif, M.D.; Stchigel, A.M.; Miller, A.N.; Huhndorf, S.M. A re-evaluation of genus Chaetomidium based on molecular and morphological characters. Mycologia 2009, 101, 554-564. [CrossRef] [PubMed]

27. Crous, P.W.; Shivas, R.G.; Quaedvlieg, W.; van der Bank, M.; Zhang, Y.; Summerell, B.A.; Guarro, J.; Wingfield, M.J.; Wood, A.R.; Alfenas, A.C.; et al. Fungal Planet Description Sheets: 214-280. Persoonia 2014, 32, 184-306. [CrossRef]

28. Miller, A.N.; Huhndorf, S.M. A natural classification of Lasiosphaeria based on nuclear LSU rDNA sequences. Mycol. Res. 2004, 108, 26-34. [CrossRef]

29. Huhndorf, S.M.; Miller, A.N.; Fernández, F.A. Molecular systematics of the Sordariales: The order and the family Lasiosphaeriaceae redefined. Mycologia 2004, 96, 368-387. [CrossRef]

30. Fernandez, F.A.; Lutzoni, F.M.; Huhndorf, S.M. Teleomorph-anamorph connections: The new pyrenomycetous genus Carpoligna and its Pleurothecium anamorph. Mycologia 1999, 91, 251-262. [CrossRef]

31. Fernandez, F.A.; Miller, A.N.; Huhndorf, S.M.; Lutzoni, F.M.; Zoller, S. Systematics of the genus Chaetosphaeria and its allied genera: Morphological and phylogenetic diversity in north temperate and neotropical taxa. Mycologia 2006, 98, 121-130. [CrossRef]

32. Chang, J.H.; Kao, H.W.; Wang, Y.Z. Molecular phylogeny of Cercophora, Podospora, and Schizothecium (Lasiosphaeriaceae, Pyrenomycetes). Taiwana 2010, 55, 110-116.

33. Rupcic, Z.; Rascher, M.; Kanaki, S.; Köster, R.W.; Stadler, M.; Wittstein, K. Two new cyathane diterpenoids from mycelial cultures of the medicinal mushroom Hericium erinaceus and the rare species, Hericium flagellum. Int. J. Mol. Sci. 2018, 19, 740. [CrossRef] [PubMed]

34. Becker, K.; Wongkanoun, S.; Wessel, A.-C.; Bills, G.F.; Stadler, M.; Luangsa-ard, J.J. Phylogenetic and chemotaxonomic studies confirm the affinities of Stromatoneurospora phoenix to the coprophilous Xylariaceae. J. Fungi 2020, 6, 144. [CrossRef]

35. Shen, K.-Z.; Gao, S.; Gao, Y.-X.; Wang, A.-R.; Xu, Y.-B.; Sun, R.; Hu, P.-G.; Yang, G.-F.; Li, A.-J.; Zhong, D.; et al. Novel dibenzo[b,e]oxepinones from the freshwater-derived fungus Chaetomium sp. YMF 1.02105. Planta Med. 2012, 78, 1837-1843. [CrossRef]

36. Viehrig, K.; Surup, F.; Harmrolfs, K.; Jansen, R.; Kunze, B.; Müller, R. Concerted action of P450 plus helper protein to form the amino-hydroxy-piperidone moiety of the potent protease inhibitor crocapeptin. J. Am. Chem. Soc. 2013, 135, 16885-16894. [CrossRef] [PubMed]

37. Kwon, H.C.; Kauffman, C.A.; Jensen, P.R.; Fenical, W. Marinomyces A-D, antitumor-antibiotics of new structure class from a marine Actinomycete of the recently discovered genus "Marinispora". J. Am. Chem. Soc. 2006, 128, 1622-1632. [CrossRef]

38. Morinaga, T.; Minoura, K.; Udagawa, S. New species of microfungi from southeast Asian soil. Trans. Mycol. Soc. Jpn. 1978, 19, 135-148.

39. Krug, J.C.; Udagawa, S.; Jeng, R.S. The genus Apiosordaria. Mycotaxon 1983, 17, 533-549.

40. Matsumori, N.; Kaneno, D.; Murata, M.; Nakamura, H.; Tachibana, K. Stereochemical determination of acyclic structures based on carbon-proton spin-coupling constants. A method of configuration analysis for natural products. J. Org. Chem. 1999, 64, 866-876. [CrossRef] [PubMed]

41. Hoye, T.; Jeffrey, C.; Shao, F. Mosher ester analysis for the determination of absolute configuration of stereogenic (chiral) carbinol carbons. Nat. Protoc. 2007, 2, 2451-2458. [CrossRef]

42. Anke, H.; Laatsch, H. 2018. Cyclic peptides and depsipeptides from Fungi. In Physiology and Genetics. The Mycota (A Comprehensive Treatise on Fungi as Experimental Systems for Basic and Applied Research); Anke, T., Schüffler, A., Eds.; Springer: Cham, Switzerland, 2018; Volume 15. [CrossRef]

43. Wittstein, K.; Cordsmeier, A.; Lambert, C.; Wendt, L.; Sir, E.B.; Weber, J.; Wurzler, N.; Petrini, L.E.; Stadler, M. Indentification of Rosellinia species as producers of cyclodepsipeptide PF1022 A and resurrection of the genus Dematophora as inferred from polythetic taxonomy. Stud. Mycol. 2020, 96, 1-16. [CrossRef] [PubMed] 
44. Caloni, F.; Fossati, P.; Anadón, A.; Bertero, A. Beauvericin: The beauty and the beast. Environ. Toxicol. Pharmacol. $2020,75,103349$. [CrossRef] [PubMed]

45. Weng, Q.; Zhang, X.; Chen, W.; Hu, Q. Secondary metabolites and the risks of Isaria fumosorosea and Isaria farinose. Molecules 2019, 24, 664. [CrossRef] [PubMed]

46. Rowin, G.L.; Miller, J.E.; Scionberg, G.A.; Onishi, J.C.; Davis, D.; Dulaney, E.L. Verlamelin, a new antifungal agent. J. Antibiot. 1986, 39, 1772-1775. [CrossRef]

47. Wang, X.; Gong, X.; Li, P.; Lai, D.; Zhou, L. Structural diversity and biological activities of cyclic depsipeptides from fungi. Molecules 2018, 23, 169. [CrossRef] [PubMed]

48. Chiang, Y.M.; Szewczyk, E.; Nayak, T.; Davidson, A.D.; Sanchez, J.F.; Lo, H.C.; Ho, W.Y.; Simityan, H.; Kuo, E.; Praseuth, A.; et al. Molecular genetic mining of the Aspergillus secondary metabolome: Discovery of the emericellamide biosynthetic pathway. Chem. Biol. 2008, 15, 527-532. [CrossRef] [PubMed]

49. Iida, A.; Mihara, T.; Fujita, T.; Takaishi, Y. Peptidic immunosuppressants from the fungus Trichoderma polysporum. Bioorg. Med. Chem. Lett. 1999, 9, 3393-3396. [CrossRef]

50. Stratmann, K.; Burgoyne, D.L.; Moore, R.E.; Patterson, G.M.L.; Smith, C.D. Hapalosin, a cyanobacterial cyclic depsipeptide with multidrug-resistance reversing activity. J. Org. Chem. 1994, 59, 7219-7226. [CrossRef]

51. Omoto, S.; Ogino, H.; Inouye, S. Studies On SF-1902 $\mathrm{A}_{2} \sim \mathrm{A}_{5}$, minor components of SF-1902 (globomycin). J. Antibiot. 1981, 34, 1416-1423. [CrossRef]

52. Kiho, T.; Nakayama, M.; Yasuda, K.; Miyakoshi, S.; Inukai, M.; Kogen, H. Synthesis and antimicrobial activity of novel globomycin analogues. Bioorg. Med. Chem. Lett. 2003, 13, 2315-3218. [CrossRef] 